\title{
Correction to: Electrochemical impedimetric biosensors for food safety
}

\author{
Changhoon Chai ${ }^{1} \cdot$ Se-Wook Oh$^{2}$
}

(C) The Author(s) 2020

\section{Correction to: Food Sci Biotechnol (2020) 29(7):879-887 https://doi.org/10.1007/s10068-020- 00776-w}

The article "Electrochemical impedimetric biosensors for food safety", written by Changhoon Chai and Se-Wook Oh, was originally published Online First without Open Access. After publication in volume 29, issue 7, page 879-887 the author decided to opt for Open Choice and to make the article an Open Access publication. Therefore, the copyright of the article has been changed to (c) The Author(s) 2020 and the article is forthwith distributed under the terms of the Creative Commons Attribution 4.0 International License (http://creativecommons.org/licen ses/by/4.0/), which permits use, duplication, adaptation, distribution and reproduction in any medium or format, as long as you give appropriate credit to the original author(s) and the source, provide a link to the Creative Commons license, and indicate if changes were made.

The original article has been corrected.

Open Access This article is licensed under a Creative Commons Attribution 4.0 International License, which permits use, sharing, adaptation, distribution and reproduction in any medium or format, as long as you give appropriate credit to the original author(s) and the source, provide a link to the Creative Commons licence, and indicate if changes were made. The images or other third party material in this article are included in the article's Creative Commons licence, unless indicated otherwise in a credit line to the material. If material is not included in the article's Creative Commons licence and your intended use is not permitted by statutory regulation or exceeds the permitted use, you will need to obtain permission directly from the copyright holder. To view a copy of this licence, visit http://creativecommons. org/licenses/by/4.0/.
The original article can be found online at https:// doi.org/10.1007/s10068-020-00776-w.

Se-Wook Oh

swoh@kookmin.ac.kr

1 Department of Applied Animal Science, Kangwon National University, Chuncheon 24341, Republic of Korea

2 Department of Food and Nutrition, Kookmin University, Seoul 02707, Republic of Korea 